\title{
MAMMALS
}

\section{HABITAT PREFERENCES OF ARCTIC SHREW IN CENTRALAND SOUTHERN ALBERTA}

JM R. SALT, E-mail: jrsalt@telus.net

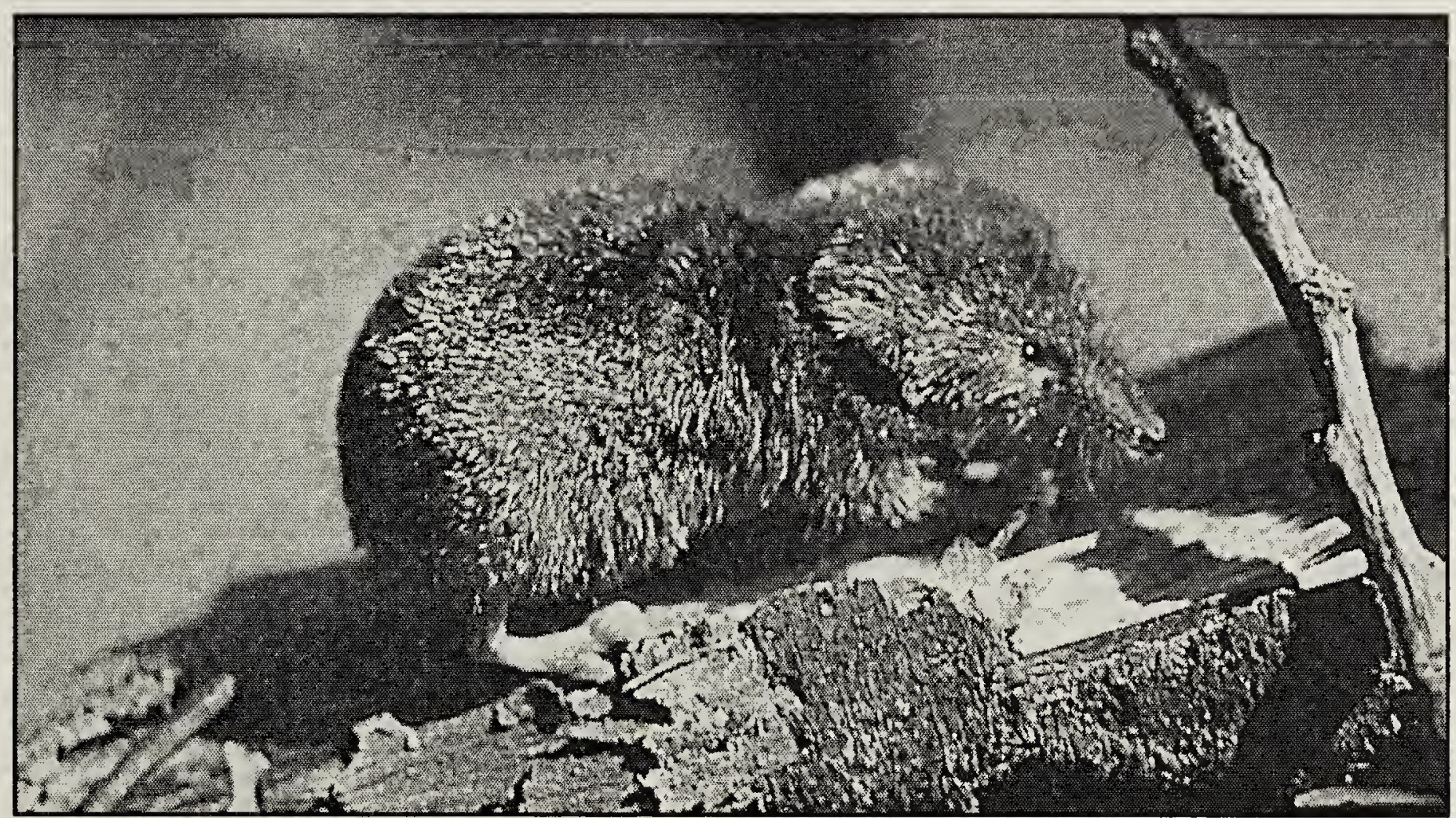

Arctic Shrew

Jim Salt

During the 1970s I conducted field studies of small mammals at many sites in western, central and southern Alberta, using a variety of trap methods. Sherman and pitfall live traps, Museum Special traps and several alternative field methods were tested repeatedly from late 1972 until 1980.

The most intensive and prolonged period of field work was conducted in the Pigeon Lake area, from Thorsby vicinity south to the northwest end of Pigeon Lake, westward some $10 \mathrm{~km}$ and south to Battle Lake and Battle Creek. This region contained examples of isolated muskegs and bogs, a variety of marshes and seasonal wetlands, deciduous and mixed woods, grazed pastures, meadows and grassy clearings. There was also one wooded site burned in May 1966, consisting of poplar (predominantly aspen) and a few lodgepole pine, growing in as dense aspen poplar. The Arctic Shrew, Sorex arcticus, was one of the three most common species recorded in central Alberta during these surveys. The present note concerns the habitat preferences of this shrew as indicated by trap captures and other detection methods, supplemented by information from previous field-workers in the areas of my studies.

According to the great majority of sources, the Arctic Shrew is found primarily in wet environments, marshes, muskegs and poorly-drained lowlands. ${ }^{1-4}$ Wrigley et al (1979) is one of the few accounts to note a wider range of possible habitats for the species. ${ }^{5}$ In fact, the results of the central 
Alberta field work in the 1970s indicated that this species occurred in greatest concentrations in a variety of dry or welldrained habitats, such as enclosed meadow, grassy woods-edges or clearings, and the higher ground associated with coniferous woods and lakes or streams. Soper (pers. comm.) had sampled with snap traps in this same area in the years 1936-37, and had found no sign of Arctic Shrew except for a single specimen at the end of Battle Lake in 1937. Lister had collected another individual at the north end of Pigeon Lake in 1952 (University of Alberta Zoology Museum specimen).

The table below contains numbers of Sorex arcticus recorded in four types of habitat by all capture methods. The data, based on a total of 154 individuals, represent records from the Pigeon Lake and Battle Lake areas, the Edmonton vicinity (Devon, Winterburn, Cawes Lake, Acheson, etc.), Dried Meat Lake, Cooking Lake vicinity, Edson and Blue Lake regions, Rocky Mountain House, Jackfish Lake and Nordegg. The four habitat types were: 1) dry, long grass in enclosed meadows, grassy margins of woods and dry stream courses; 2) the interiors of mature poplar and mixed woods, particularly those with some deadfall, and small clearings; 3 ) seasonally wet areas, willow margins near sloughs and ponds, boulder banks of lakes or rivers, stream or pond banks well above water-line; and 4) permanently damp lowlands such as bog, muskeg or marsh.

A total of 160 Arctic Shrew records was examined. When grouped simply according to "dry, well-drained" or "wet, poorly drained" environments, at least 121 (more than $76 \%$ ) of Arctic Shrew captures were made in the dry locations; about 33 (20\% of captures) were taken in permanently damp to wet areas, while no ecological data were available for the remaining 6 records.

Of the other species found during these surveys at the same trap stations with Arctic Shrew, the Red-backed Vole (Clethrionomys gapperi) was the most numerous, followed by Masked Shrew (Sorex cinereus). Less numerous and more ecologically restricted species were Meadow Vole (Microtus pennsylvanicus), Dusky Shrew (Sorex monticolus), Deer Mouse (Peromyscus maniculatus), Water Shrew (Sorex palustris) and Meadow Jumping Mouse (Zapus hudsonius). The proportions and numbers of each species varied with specific habitat.

\begin{tabular}{|c|c|c|c|}
\hline $\mathbf{1}$ - Meadow/Edges & 2 - Woods & 3 - Seasonally wet & 4 - Bog/muskeg \\
\hline 98 & 24 & 19 & 13 \\
\hline
\end{tabular}

1. BUCKNER, C.H. 1966. Populations and ecological relationships of shrews in tamarack bogs of southeastern Manitoba. Journal of Mammology. 47(2): 181 .

2. CLOUGH, G.C. 1963. Biology of the arctic shrew, Sorex arcticus. American Midland Naturalist 69: 69.

3. SOPER, J.D. 1964. The Mammals of Alberta. Hamly Press, Edmonton; 402p. + Index.
4. VAN ZYLL DE JONG, C.G. 1983. Handbook of Canadian Mammals. 1. Marsupials and insectivores. Nat. Mus. Nat. Sci., Nat. Mus. of Canada.

5. WRIGLEY, R.E., J.E. DUBOIS \& H.W.R. COPELAND. 1979. Habitat, abundance, and distribution of six species of shrews in Manitoba. Jonrnal of Mammology 60: 505-520. 